\title{
Newfoundland and Labrador
}

n April $24^{\text {th }}-25^{\text {th }}$, the Newfoundland and Labrador Department of Natural Resources held a Forestry Fair in Corner Brook. The purpose of the fair was to showcase all aspects of forest and wildlife management with special emphasis on the huge variety of products that we derive from the forests. The Section jumped at the opportunity to participate, and a booth showcasing the Institute, Think Forests and Forests without Borders was erected. Literature was provided to fair participants on the 3 topics, as well as plenty of lively conversation on the merits of our organization and the many initiatives both locally and nationally. Friday was mostly set aside for elementary school children who when visiting our booth were asked a variety of forestry-related "treevia" questions. We were pleasantly surprised at the level of knowledge shown by the children, especially regarding tree components, forest products and local forest species.

Some 3000 people visited the fair and hopefully left with a greater appreciation for the level of effort, that goes into forest management and the many activities that fall under the CIF/IFC organization. A special thank you is extended to the local Section members who gave up a part of their weekend to work the booth. I personally would like to thank Bill Clarke for his help and for spearheading the Forests without Borders program in the Atlantic Region.

On May 7, 2009, the Section continued its series of mini-forums by co-hosting a series of technical presentations at the Hotel North Two in Goose Bay, Labrador. The meeting was cosponsored by the Model Forest of Newfoundland and Labrador, which has partnered with the Section to bring these forums to the public as well as to our members. Veering from the norm of a single presentation over lunch, the forum presented the 20-plus attendees with 4 speakers. Gary Forward, Development Specialist with DNR presented a variety of value-added development opportunities focusing on the dense black spruce forests of Labrador. Bill Alexander (Director of the Newfound-

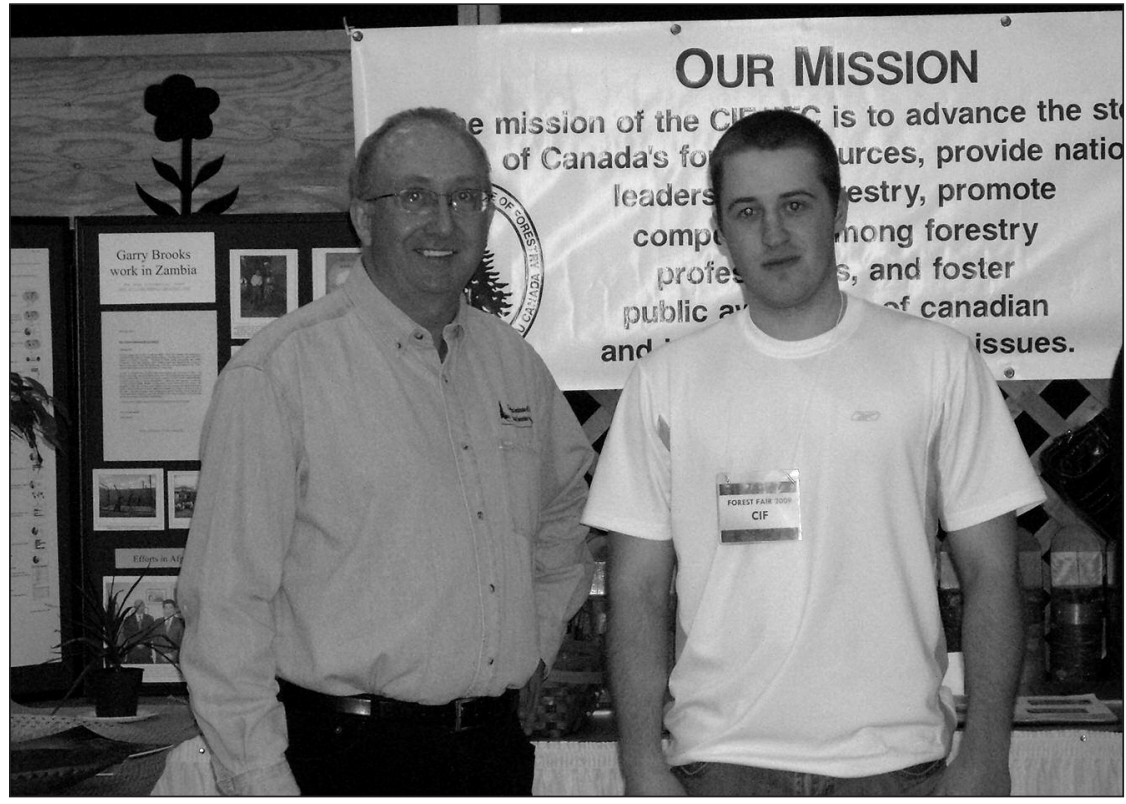

CIF/IFC booth with $2^{\text {nd }}$ VP National Wayne Kelly and NL Section Student Councilor Justin Mutford

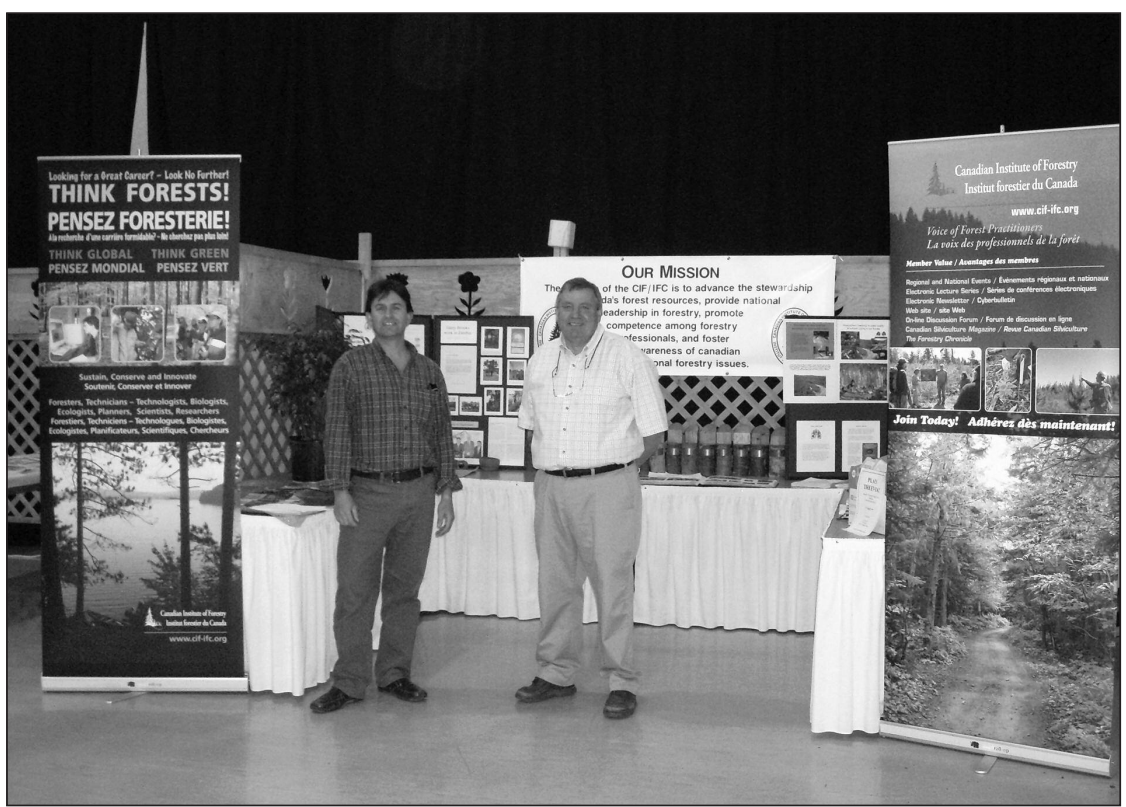

The complete CIF/IFC booth with NL Director Eric Young (left) and incoming Director Allan Masters prior to opening of fair.

land and Labrador Forestry Training Association) examined the growing use of biomass, wood fuels and wood pellet production in and around central Europe. Both presented strong cases for the potential development of the forest resources in Labrador. There was plenty of discussion from the audience, which delayed the serving of the local caribou stew (aka lunch). The afternoon session 
looked at natural disturbances starting with the presentation of a UNB Master's thesis by Jason Glode on windthrow prediction modeling in insular Newfoundland.

Although Jason's work focused on the forests of the Island, the potential to test the model with Labrador data was evident. Darren Jennings, a Regional Planner for DNR, rounded up the ses-

\section{Orléans}

Colloque annuel du CEF-Gatineau

e 19 et 20 avril dernier sest tenu le $3^{\text {ème }}$ colloque annuel du Centre détude de la forêt (CEF)/Centre for Forest Research (CFR) (www.cef-cfr.ca). Le $\mathrm{CEF}$ est un regroupement universitaire unique au Québec puisqu'il réunit lexpertise scientifique québécoise œuvrant en forêt. Ce centre regroupe, actuellement, 49 chercheurs réguliers répartis dans 8 universités québécoises (Concordia, McGill, l'UQAC, l'UQÀM, l'UQAT, l'Université de Montréal, l'Université de Sherbrooke et l'Université Laval), près de 23 chercheurs associés répartis dans des universités à l'international et divers centres de recherches gouvernementaux. Enfin, plus d'une centaine détudiants au doctorat et plus de 150 étudiants à la maîtrise évoluent au sein du plus grand groupe de recherche dans le domaine de l'écologie forestière au Canada et l'un des plus importants au monde. La direction du Centre est assumée par le professeur Christian Messier du Département des Sciences biologiques de l'Université du Québec à Montréal.

Cette année, le colloque annuel a eu lieu à Gatineau au même endroit et juste avant le dernier colloque du Réseau des Centres d'excellence en gestion durable des forêts (RGDF). Tous les membres du CEF y étaient invités afin, notamment, d’améliorer le maillage avec leurs collègues des autres provinces. Ce colloque est également loccasion, chaque année, pour tous les membres de présenter leurs travaux de recherche sous forme de présentations orales ou daffiches scientifiques. Un total de 123 participants ont répondu à l'invitation. Pour ce $3^{\text {ème }}$ colloque, la conférence de fermeture a été présentée par monsieur Vic Adamowicz, titulaire de la Chaire de recherche du Canada en économie sion by discussing the instances of natural disturbances such as fire, insects and windthrow. While there is a long history of fire in Labrador it is only within the last few years that insects (hemlock looper and spruce budworm) have shown a presence in the local forests. This has prompted a DNR insect control program and a research study on Labrador looper by CFS and DNR. Copies of all presentations are available by contacting CIF/NL (or emailing emyoung@gov.nl.ca). A special thank you is extended to the Model Forest, forum participants and to all speakers, especially Darren who helped organize the day, presented and recommended the caribou.

Eric Young

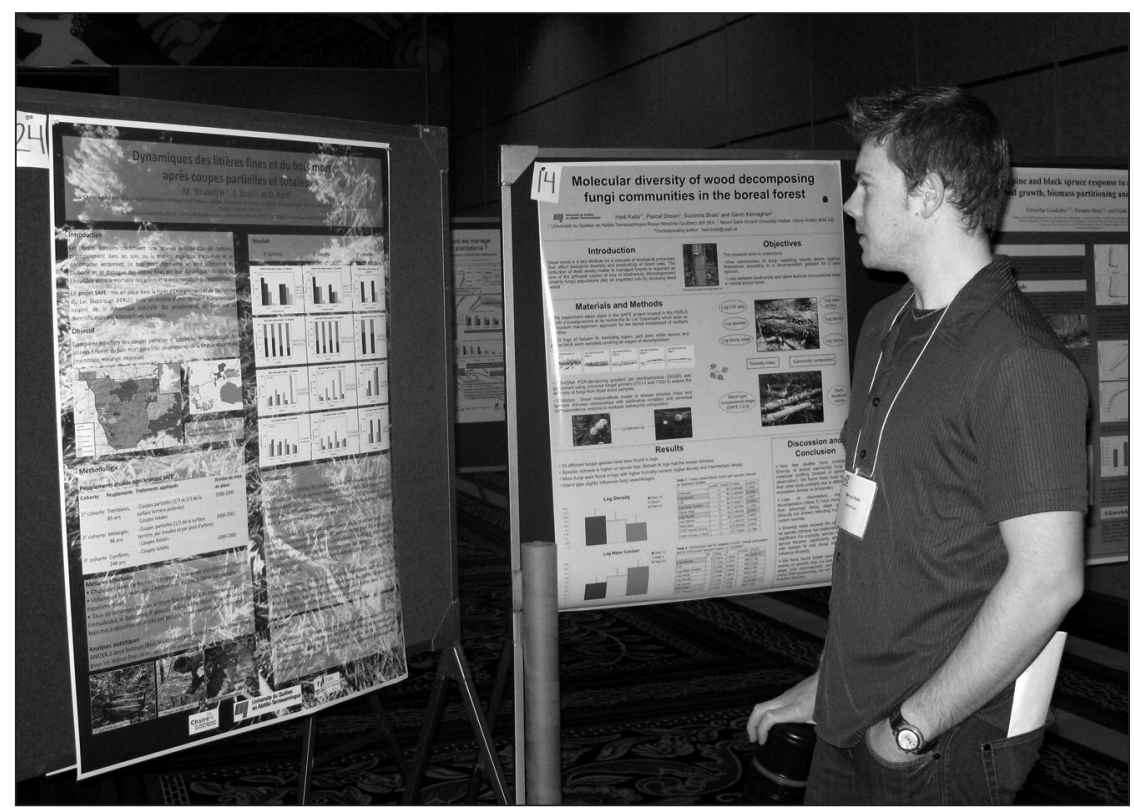

Séance d'affiches - Pierre-Luc Poulin, professionnel de recherche, Arborea, Université Laval.

environnementale et professeur en économie rurale et forestière de l'Université d'Alberta. Le professeur Adamowicz est aussi récipiendaire du Prix d'excellence en sciences forestières au Canada de l'Institut forestier du Canada en 2004. Finalement, il est membre de la société royale du Canada, il fut directeur scientifique du RGDF et il est connu mondialement pour ses travaux en économie et environnement. Sa présentation était intitulée : "The Challenge of Biodiversity Conservation in Forests: Can Markets for Ecosystem Services Help?."

De nombreux membres du CEF sont ou pourraient être membres de l'Institut forestier du Canada. C'est une des raisons pour laquelle l'IFC/CIF, représenté notamment par John Pineau et Caroline Plante, a participé à ce colloque, pas le biais d'une commandite, d'un stand et en organisant un concours pour récompenser l'auteur de la meilleure affiche scientifique. Pendant les deux jours du colloque, chaque participant était invité à voter pour l'affiche qu'il préférait. Cette année, l'affiche qui a recueilli le plus de votes était intitulée «Les coupes partielles pour conserver les éléments structuraux et la biodiversité en pessière » et avait pour premier auteur Joshua JACOBS, étudiant au doctorat à l'UQȦM avec pour coauteurs Timothy Work (UQÀM) et Hervé Bescond (UQAT). Voici le résumé de cette affiche :

"Les débris ligneux grossiers (DLG) sont identifiés comme étant des éléments critiques d'habitat pour de nombreuses espèces en forêt. La récolte forestière diminue la quantité de DLG à long terme, ce qui menace grandement les espèces adaptées au bois mort. Les coupes partielles sont une stratégie d'aménagement forestier pour conserver les éléments structuraux et la biodiversité des forêts. Nous avons étudié la quantité de 


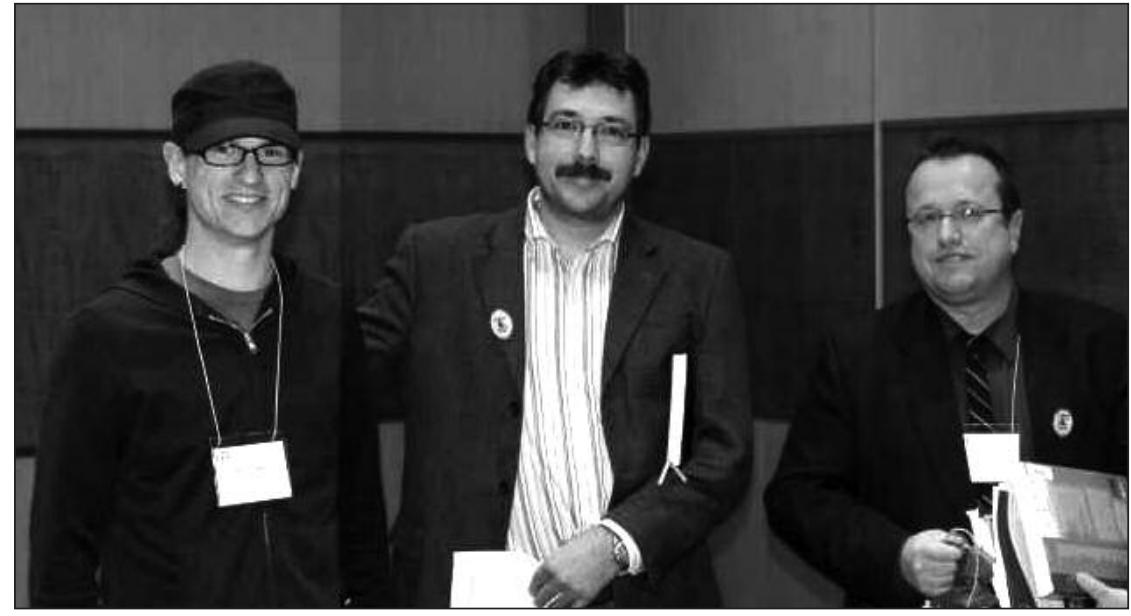

Joshua Jacobs reçoit son prix pour la meilleure affiche scientifique des mains de Christian Messier, directeur du CEF et John Pineau, directeur exécutif de l'IFC.

DLG et la biodiversité des coléoptères associés au bois mort dans les peuplements témoins ceux ayant fait l'objet de coupes partielles $(C P)$ et de coupes avec protection de la régénération et des sols (CPRS) en pessière. Il n'y avait pas une

\section{Algonquin}

\section{Celebrating the Institution of Marriage}

0 Friday May 22, members of the Section hosted a unique event collectively celebrating longevity of marriage. Section Director Andrée Morneault booked the Urban Café in North Bay for an evening of revelry, good food and drink; and the Café chefs certainly came through, delighting all with their culinary expertise.

The statistics were impressive. The group of 11 couples managed a total of 274 years of uninterrupted marriage. Leading the charge were Dave and Cathy Payne at 35 years, Bob Aubin and Cathy Orland at 33 years and Brian and Jody Batchelor at 32 years! There was much praise for Jody's patience and perseverance in particular, from all in attendance!

The evening also allowed for some fund-raising for the Institute's new Forests without Borders program. Over $\$ 120$ was raised!

"It was a fun night," said Andrée. "It was the Institute at its best—good times, lively discussion, and supporting a good cause. We will do this again." grande différence de quantité de DLG entre les témoins, $C P$ et CPRS dans les premiers 5 ans après la coupe, mais les différences entre la quantité de DLG devrait devenir évidentes quand les arbres vivants commenceront à mourir. Il $y$ avait une différence significative des assemblages de coléoptères entre les témoins et les peuplements coupés (CP et $C P R S)$. Les peuplements coupés étaient plus diversifiés (diversité alpha), mais les témoins étaient plus variables entre les sites (diversité bêta). Les coupes partielles ne semblent pas une bonne stratégie pour conserver les coléoptères à court terme, cependant les bénéfices des coupes partielles pour les coléoptères associés au bois mort devraient être observés avec l'augmentation des DLG avec le temps suivant ces traitements. Les coupes partielles ont encore la possibilité de conserver les éléments structuraux et d'augmenter le taux de rétablissement des éléments de biodiversité comme les coléoptères. "

Le prix remis offrait un an de cotisation à l'IFC un ensemble de tire-bouchon aux couleurs de l'IFC accompagné d'une bouteille de vin pour lessayer. Joshua a reçu son prix des mains de Christian Messier, directeur du CEF et de John Pineau, directeur exécutif de l'IFC.

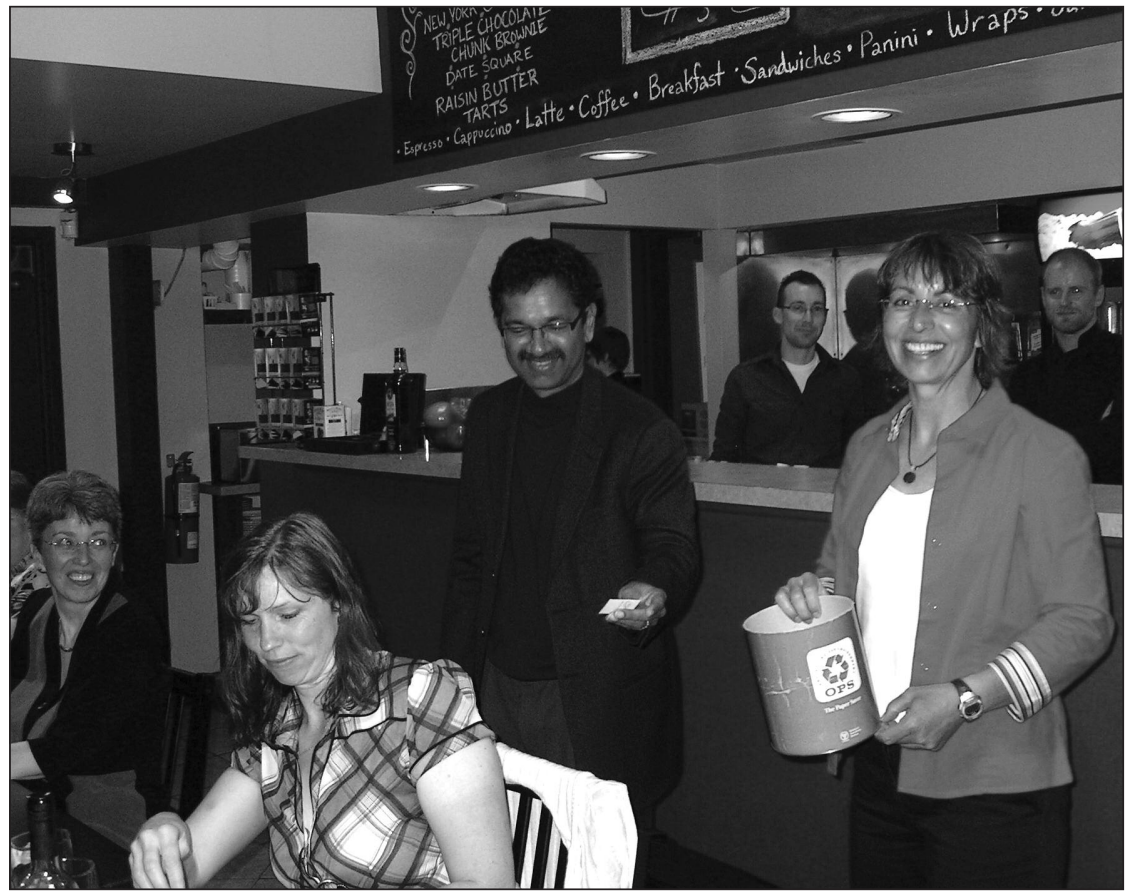

Fred and Andrée raise funds for Forests without Borders.

Another positive outcome of the evening was the discovery of the ultimate hardhat hairdo! Sporting the retro-1960ish style was Jody Batchelor. There is no doubt that hardhats are conducive to bad-hair days, particularly for the female forest practitioner. The new "do" is attractive and stylish, and deemed highly resistant to the detrimental hair effects of the typical hardhat. For more information, please contact questions@cif-ifc.org. 


\section{Rocky Mountain}

The Section would like to introduce our 2009 council. We are welcoming a few new members and saying a fond goodbye to a couple of others. Incoming council members are Stan Kavalinas, Teresa Stokes, Alex Drummond and Jason Proche. It would be stretching the truth a bit to suggest that Stan, Teresa and Alex are new to the RMS council, as all have served previously. It is always heartening to know that people are willing to come back and volunteer their time again. It must mean the experience was a positive one the first time around! Jason Proche is a newcomer to council and we also welcome his perspective and ideas.

Mark Kube is moving from the Chair to the Director's seat and Anand Pandarinath will take over as the Chair. Sarah Gooding has graciously volunteered to be the new Vice-Chair and Lorne West was talked into taking over the role of Treasurer. Cynthia Chand will continue to provide her valuable support in the role of council Secretary and Wendy Crosina, and Dave McNabb will continue their role as council members. Both Wayne Williams (CAPFT) and Doug Krystofiak (CAPF) will also continue in their roles as liaison to their professional organizations.

We say a fond farewell to long-standing council members Bev Wilson and Janis Braze. Both Bev and Janis worked hard to make the RMS council a success and we appreciate their time and dedication to their roles. We would also like to thank our outgoing University of Alberta representatives Jennifer Platz and Sarah Railton. Having student voices on the RMS council provided a much-needed perspective on our future professionals.

RMS put on 2 technical sessions in Alberta this past year. The first was held in June 2008, in conjunction with the CAPF Annual General Meeting. The topic was "Reclamation and Remediation Professional Sign off - Implications for Natural Resource Managers." Close to 80 people attended, learning how the new professional sign-off on reclamation and remediation may affect them.

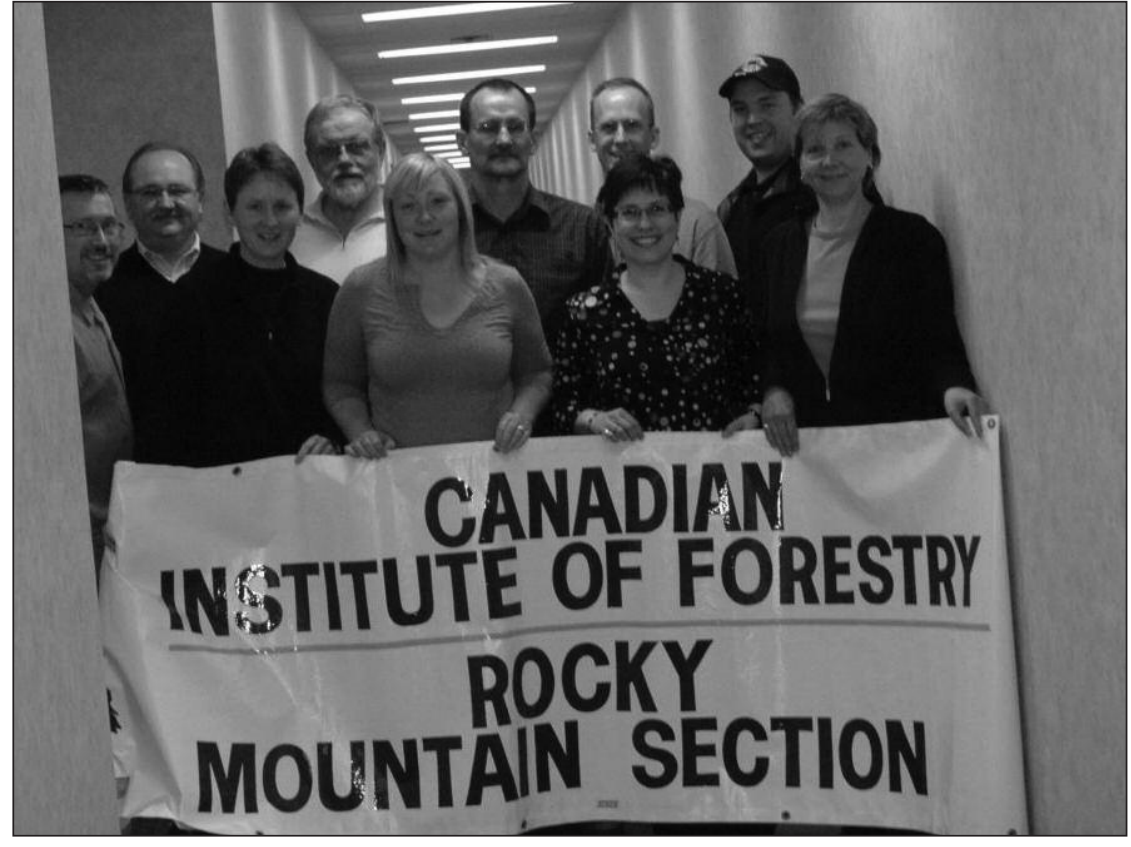

The 2009 CIF-RMS Council: (L-R) Doug Krystofiak, Lorne West, Wendy Crosina, Dave McNabb, Cynthia Chand, Stan Kavalinas, Teresa Stokes, Mark Kube, Wayne Williams, Sarah Gooding. Absent are Anand Pandarinath, Jason Proche and Alex Drummond.

The second session, "Grizzly Bear Management in Alberta", was held in January. The capacity crowd of close to 140 people enjoyed the excellent line-up of speakers with many different viewpoints. A total of 28 students from the University of Alberta, the University of Calgary and Lakeland College attended the session as well.

The University of Alberta Department of Renewable Resources Forestry and Forest Business Management Graduates held their banquet and award ceremonies Saturday, March 28 at the Faculty Club. Family, friends, and Faculty members honored 13 members of the 2 programs. Mark Kube, Chair and Anand Pandarinath, Director (2008-09), Rocky Mountain Section, presented the CIF/IFC Silver Rings. Masters of Ceremonies, Darrick Brochu and Amanda Horning, did a great job of entertaining grads and guests. Guest speaker for the evening was Professor Marty Luckert. Valedic-torian Kirk Hawthorn was also announced as the recipient for the CIF/IFC Gold Medal award. The Gold Medal is awarded to a graduating Forestry/Forest Business Management student who displays out-

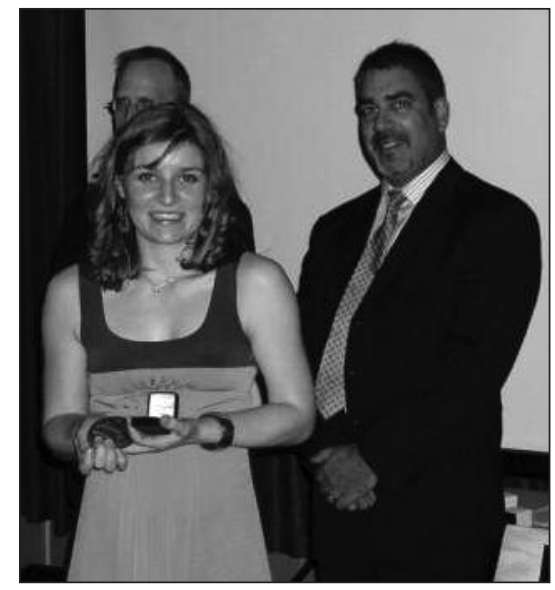

University of Alberta Department of Renewable Resources Forestry and Forest Business Management Valedictorian Kirk Hawthorn was announced as the nominee for the CIF/IFC Gold Medal; right is Section Director Anand Pandarinath, behind is Section Chair Mark Kube.

standing scholarship, sportsmanship and citizenship throughout the years of the program. This medal will be officially awarded at the end of term. Congratulations to the class of 2009. 